\title{
Appraisal of chromium and cobalt contents of vegetables grown in soil irrigated with sewage water: A risk for consumers' health
}

\author{
Zafar Iqbal Khan ${ }^{1 *}$, Anam Nisar $^{1}$, Ilker Ugulu$^{2}$, Kafeel Ahmad ${ }^{1}, K_{\text {Kinza Wajid }}{ }^{1}$, \\ Muhammad Nadeem ${ }^{3}$, Tahir Mehmood Qureshi ${ }^{3}$, Farzana Shaheen ${ }^{1}$, Shahzad \\ Akhtar $^{1}$, Humayun Bashir ${ }^{1}$, Mudasra Munir ${ }^{1}$, Ijaz Rasool Noorka ${ }^{4}$, Khalid \\ Nawaz $^{5}$, Mahpara Shehzadi ${ }^{6}$, Naunain Mehmood ${ }^{7}$, Ifra Saleem Malik ${ }^{1}$, Hafsa \\ Memona $^{8}$, Madiha Sana ${ }^{8}$, Asma Ashfaq ${ }^{1}$, Rabia Abdullah ${ }^{1}$, Sana Iqbal ${ }^{1}$, Fauzia \\ Batool $^{1}$, Mian Jahan Zaib Rasheed ${ }^{1}$, Samra Siddique ${ }^{1}$, Abrar Hussain ${ }^{9}$, Fahim
} Arshad $^{10}$, Taswar Abbas ${ }^{11}$, Saif Ullah ${ }^{12}$ and Hira Muqadas ${ }^{13}$

1. Department of Botany, University of Sargodha, Sargodha-Pakistan

2. Buca Faculty of Education, Dokuz Eylul University, Izmir-Turkey

3. Institute of Food Science and Nutrition, University of Sargodha, Sargodha-Pakistan

4. Plant Breeding and Genetics, Agriculture College, University of Sargodha, Sargodha-Pakistan

5. Department of Botany, University of Gujrat, Gujrat-Pakistan

6. Department of Agriculture, Ghazi University, Dera Ghazi Khan-Pakistan

7. Department of Zoology, University of Sargodha-Pakistan

8. Department of Zoology, Lahore College for Women University, Lahore-Pakistan

9. Department of Botany, University of Education, Township Campus, Lahore-Pakistan

10. Department of Botany, University of Okara-Pakistan

11. Department of Earth Sciences, University of Sargodha, Sargodha-Pakistan

12. Department of Economics, University of Sargodha-Pakistan

13. Department of Zoology, Women University Multan-Pakistan

*Corresponding author's email:_zafar.khan@uos.edu.pk

\section{Citation}

Zafar Iqbal Khan, Anam Nisar, Ilker Ugulu, Kafeel Ahmad, Kinza Wajid, Muhammad Nadeem, Tahir Mehmood Qureshi, Farzana Shaheen, Shahzad Akhtar, Humayun Bashir, Mudasra Munir, Ijaz Rasool Noorka, Khalid Nawaz, Mahpara Shehzadi, Naunain Mehmood, Ifra Saleem Malik, Hafsa Memona, Madiha Sana, Asma Ashfaq, Rabia Abdullah, Sana Iqbal, Fauzia Batoo, Mian Jahan Zaib Rasheed, Samra Siddique, Abrar Hussain, Fahim Arshad, Taswar Abbas, Saif Ullah and Hira Muqadas. Appraisal of chromium and cobalt contents of vegetables grown in soil irrigated with sewage water: A risk for consumers' health. Pure and Applied Biology. Vol. 8, Issue 1, pp804-812.

http://dx.doi.org/10.19045/bspab.2019.80010

Received: 06/11/2018 Revised: 11/01/2019

Accepted: 12/01/2019

Online First: 17/01/2019

\section{Abstract}

The aim of the present research was to determine the concentrations of chromium $(\mathrm{Cr})$ and cobalt (Co) in soil, vegetables grown at the areas which are usually irrigated with canal water (CW) and sewage water (SW). The samples were analysed through Atomic Absorption Spectrophotometer. The mean concentrations of $\mathrm{Cr}$ and $\mathrm{Co}$ in soil samples varied from 0.9 to $1.80 \mathrm{mg} / \mathrm{kg}$ and 0.575 to $1.10 \mathrm{mg} / \mathrm{kg}$, respectively. The highest value of Cr was observed in Solanum lycopersicum irrigated with SWI and the lowest in Brassica rapa irrigated with CW. While in case of cobalt, the highest value was found in Solanum lycopersicum irrigated with SW and the lowest was noticed in Capsicum baccatum irrigated with $\mathrm{CW}$. In all vegetables, the daily intake of metal values for $\mathrm{Cr}$ 
and Co were higher in SWI as compared to the CWI. Bio-concentration factor values of heavy metals were less than 1 in all vegetables for $\mathrm{Cr}$ and $\mathrm{Co}$, and these results specified that metal bioavailability was low at CWI and SWI. Health Risk Index values of $\mathrm{Cr}$ and Co were less than one. The findings suggested that the locals were safe while consuming these vegetables but consistent use of waste water may increase the risk of contaminants as they may reach the toxic levels.

Keywords: Chromium; Cobalt; Wastewater; Vegetables

\section{Introduction}

Trace metals are potentially toxic and even lesser quantities of these metals in organisms are harmful as they are utilized in industrial processes [1]. Trace metals could be collected in the food stuff consumed by humans and other living beings [2]. Wastewaters have higher concentration of potentially toxic metals $[3,4]$. The infectivity of vegetables by these metals could be because of excessive use of sewage water in irrigation $[5,6]$. Extended ingestion of these heavy metals by consuming contaminated vegetables could be lethal to humans and organisms resulting in many biological disorders $[7,8]$.

The levels of trace metals are increasing day by day in ecosystems and cause uneasiness among people because of occurrence of trace metal remains $[9,10]$. The community has become fearful and worried regarding the safety of vegetables because the food items having heavy metals are not considered appropriate for consumption. Hazards related to utilization of contaminated food items have increased manifolds [11, 12]. Pollution by trace metals is owed to usage of industrial wastewater, automobiles, organic substances used for enhancing plant growth, pesticides and harvesting processes $[13,14]$. The food components absorb trace metals from land polluted with wastewater $[15,16]$. By observing the possible hazards of trace metals, their constant life and the regular use of contaminated vegetables, the matter of concern is to examine the toxic levels in food items to protect humans from health hazards $[17,18]$.
The main objective of the present research, therefore, was to determine the concentration of chromium and cobalt in vegetables grown at the areas which were usually irrigated with canal water and wastewater. The soil was also observed for its metal content at two sites i.e. site I, where canal water was used for irrigation and site II, where industrial wastewater was used. Moreover, fitness of these vegetables for human consumption was evaluated.

\section{Materials and methods Study area}

The present research was performed in an urban area of Sargodha, Punjab, Pakistan. This city has tolerable winter season and warm temperature in months from May to July. The temperature differs from 25 to 50 ${ }^{\circ} \mathrm{C}$ in the summer. The main production of this city is citrus fruit. Areas irrigated with sewage and canal water in Sargodha were selected for this study. The land used in agriculture is saline in nature. Mostly the areas surrounding Sargodha are irrigated with the industrial wastewater. Two sites were selected for study i.e. site I, where canal water was used for irrigation and site II, where industrial sewage water was used.

\section{Sample preparation}

In this study, Raphanus sativus L. (roots), Brassica rapa L. (roots), Zingiber officinale Roscoe (roots), Capsicum baccatum L. (fruit), Capsicum frutescens L. (fruit), Capsicum annuum L. (fruit), Solanum lycopersicum L. (fruit) and Curcuma longa L. (rhizome) were chosen as vegetable samples. All these samples were collected at maturity. 


\section{Wet digestion process}

The procedure for sample arrangement and preparation involved the wet digestion process. This process involved following steps: Firstly, complete digestion of samples was done by using acid and hydrogen per oxide. After digestion, the samples were diluted with distilled water and filtered through Whatman filter paper. Wet digestion breaks down organic components found in plant tissue into $\mathrm{CO}_{2}$ by strong reducing agents. After the wet digestion process, a colourless transparent and clear solution is obtained.

Firstly, soil was weighed, and $1 \mathrm{~g}$ sample was added in flask with $20 \mathrm{ml}$ of nitric acid and $10 \mathrm{ml}$ of hydrogen per oxide to be eventually placed on hot plate for heating till boiling. After removing the sample from hot plate, the sample was allowed to cool down. Samples were then filtered and put in clean plastic bottles till futher use after making volume upto $50 \mathrm{ml}$ by adding distilled water.

For plants, the parts were first converted into powdered form and then dried completely in oven for $24 \mathrm{~h}$. The samples were then added to the digestion flask with hydrochloric acid and nitric acid in 1:3 ratio. Hotplate boiling was done till achieving transparent solution which was allowed to cool. The volume of the solution was made $50 \mathrm{~mL}$ ater filtration through Whatman filter paper. The bottles were labelled and stored till further use.

\section{Chromium and cobalt analysis}

The analysis of heavy metals requires the formulation of specific standard solution for the heavy metals that are under research. Before starting the analysis of $\mathrm{Cr}$ and $\mathrm{Co}$, the formulation of the standard solution was done. After formulation of specific standard solution, the heavy metal analysis done with atomic absorption spectrophotometer (AAS6300 Shimadzu Japan).

\section{Preparation of the standard solution Statistical analysis}

Among different plants (crops) and soil samples, the degree of variation was measured by using SPSS 22 (Statistical Package for Social Sciences). To measure the mean concentration values for soil and food crop samples, one-way ANOVA was conducted.

\section{Daily intake of metals (DIM)}

The normal value of DIM is $0.242 \mathrm{~kg}$ with standard human mean weight of $55.9 \mathrm{~kg}$. It is defined as the amount calculated to the intake of trace metals orally which was obtained by formula given by Sajjad et al. [19].

$\mathrm{DIM}=($ Concentrations of metal $) \mathrm{x}$ Daily consumption of vegetable $(\mathrm{kg}$ per person)/Average body weight of a person

\section{Pollution load index (PLI)}

The presence of heavy metals in soil was assessed by this factor. By relating the amount of trace element in the polluted soil under consideration with reference to the amount of the same trace element as mentioned by the reference value of that element in soil, PLI is measured [20]. It is calculated by following formula:

$\mathrm{PLI}=$ metal concentrations in soils/metal concentration taken as reference

\section{Health risk index (HRI)}

Health risk index is calculated relative to DIM value and relative dose (RfD). The formula described by Cui et al. [20] is used to measure the relative measurement of HRI. $\mathrm{HRI}=\mathrm{DIM} /$ food oral reference dose for the metal

\section{Bio-concentration factor (BCF)}

The concentration of a substance in the tissue of organism is called bio-concentration factor (BCF). It is also known as enrichment factor or biomagnification factor. It is measured by the following formula:

$\mathrm{BCF}=$ Vegetable metals/Soil metals 


\section{Results and discussion}

Chromium and cobalt concentrations in soil samples

The mean $\mathrm{Cr}$ concentration in soil varied from 0.9 to $1.80 \mathrm{mg} / \mathrm{kg}$. Higher $\mathrm{Cr}$ values in soil were observed during sewage water irrigation and lower values were found in canal water irrigation. The ANOVA results showed that the irrigation water had significant effect $(p \leq 0.05)$ on the $\mathrm{Cr}$ concentration in soil (Table 1). The mean Co concentration in soil ranged from 0.575 to $1.10 \mathrm{mg} / \mathrm{kg}$. Higher Co values in soil were observed during sewage water irrigation. The ANOVA results showed that the irrigation water had significant effect $(p \leq 0.05)$ on the Co concentration in soil (Table 1).

Soil serves as the most central component in agricultural environment and contents of heavy metals and various other minerals in soil determine the accretion of heavy metal in plant body. In the present study, the mean $\mathrm{Cr}$ concentration in soil ranged between 0.9-1.80 $\mathrm{mg} / \mathrm{kg}$. The $\mathrm{Cr}$ levels in the soil samples investigated in the present research were lower than the maximum permissible limit of $\mathrm{Cr}(100 \mathrm{mg} / \mathrm{kg})$ reported by WHO [21]. The present $\mathrm{Cr}$ concentrations in soils were also lower than the values obtained by Haiyan and Stuanes [22] who found $\mathrm{Cr}$ concentration to be approximately $108(\mu \mathrm{g} / \mathrm{g} \mathrm{DW})$. According to Gupta et al. [23], level of $\mathrm{Cr}$ in soil elevate through application of wastewater. The concentration of $\mathrm{Co}$ in soil fell within the permissible limit of $100 \mathrm{mg} / \mathrm{kg}$ given by FAO/WHO [24]. Cobalt content in the current research was higher than the findings of Ahmad et al. [12].

\section{Chromium concentration in vegetable samples}

In the present study, the mean $\mathrm{Cr}$ concentrations $(\mathrm{mg} / \mathrm{kg})$ ranged from 0.303 0.600 ( $R$. sativus), 0.110-0.216 (B. rapa), 0.241-0.470 (Z. officinale), 0.196-0.393 (C. baccatum), 0.144-0.288 (C. frutescens), 0.190-0.378 (C. аппиит), 0.221-10.428 ( $S$. lycopersicum) and 0.250-0.525 (C. longa) (Table 1). Higher $\mathrm{Cr}$ values were observed in $S$. lycopersicum irrigated with sewage water and lower $\mathrm{Cr}$ contents were noticed in B. rapa irrigated with canal water. According to the ANOVA results the irrigation water had significant effect $(p \leq 0.05)$ on the $\mathrm{Cr}$ concentrations in $R$. sativus, B. rapa, $Z$. officinale, $C$. frutescens, $C$. annuum and $C$. longa whereas non-significant effect (p>0.05) was noticed in $C$. baccatum and $S$. lycopersicum (Table 1).

The $\mathrm{Cr}$ levels in the vegetable samples investigated in the present research were lower than the maximum permissible limit of $50 \mathrm{mg} / \mathrm{kg}$ reported by Chiroma et al. [25]. The investigated values of $\mathrm{Cr}$ were also lower than the study conducted by Nagajyoti et al. [26] who found $\mathrm{Cr}$ concentration in five leafy vegetables ranging from 0.89 to $1.08(\mu \mathrm{g} / \mathrm{g})$ except for $S$. lycopersicum. Haiyan and Stuanes [22] reported that the $\mathrm{Cr}$ content in the vegetables grown in controlled area ranged from 0.4 to 2.7 ( $\mu \mathrm{g} / \mathrm{g}$ of dw). The total $\mathrm{Cr}$ levels in edible portions of vegetables were similar to the values found in presumably less contaminated areas, such as Jiangsu, China $(0.67 \mathrm{mg} / \mathrm{kg})$ [27] and Brazil (0.01-0.6 mg/kg) [28]. Higher concentrations of total $\mathrm{Cr}$ in China region may be expected due to the mass production of refractory materials in Changxing county, especially in where there are many refractory factories [27].

Anwanghe et al. [29] reported $\mathrm{Cr}$ values $(0.06-0.14 \mathrm{mg} / \mathrm{kg} ; \quad 0.02-0.44 \mathrm{mg} / \mathrm{kg})$ in vegetables that were in accordance with the present research. Difference could be attributed to change in climate or season or other environmental factors. The EU Standards for the metal in soils and vegetables are 150 and $0.3 \mathrm{mg} / \mathrm{kg}$, respectively. Chromium does not apparently pose a health threat in the farm soils and vegetables. 
In different vegetables the mean $\mathrm{Co}$ concentrations $(\mathrm{mg} / \mathrm{kg})$ ranged between 0.106-0.211 ( $R$. sativus), 0.096-0.195 (B. rapa), 0.078-0.155 (Z. officinale), 0.0600.120 (C. baccatum), 0.060-0.120 (C. frutescens), 0.094-0.186 (C. annuum), 0.1190.236 (S. lycopersicum) and 0.158-0.311 (C. longa) (Table 1). Higher Co values were observed in S. lycopersicum irrigated with sewage water and lower Co contents were noticed in $C$. baccatum irrigated with canal water. According to the ANOVA results, the irrigation water had significant effect $(p \leq 0.05)$ on the Co contents in $R$. sativus, $Z$. officinale, $C$. frutescens, $C$. annuum, $S$. lycopersicum and $C$. longa while nonsignificant effect ( $>>0.05)$ was observed in $B$. rapa and $C$. baccatum (Table 1 ).

Cobalt is a basic component of vitamin-B12. It is essential in synthesis of red blood cells and prevents anemia. Too much intake of cobalt may cause overproduction of red blood cells [30]. The Co content in vegetables samples was found within the allowable limit of $50 \mathrm{mg} / \mathrm{kg}$ suggested by FAO/WHO [24]. Cobalt content in all vegetables was similar to the range of 0.02 $0.22 \mathrm{mg} / \mathrm{kg}$ given by Ahmad et al. [12].

\section{Bioconcentration factor}

The $\mathrm{BCF}$ values of $\mathrm{Cr}$ and $\mathrm{Co}$ in various vegetables are presented in (Table 2). In different vegetables, the BCF values of $\mathrm{Cr}$ differed from 0.333 to 0.336 ( $R$. sativus), 0.120-0.122 (B. rapa), 0.261-0.268 ( $Z$. officinale), 0.218-0.218 (C. baccatum), 0.160-0.160 (C. frutescens), 0.210-0.211 (C. annuиm), 0.238-0.246 (S. lycopersicum) and 0.278-0.292 (C. longa). High BCF values were recorded for $R$. sativus in canal water irrigation. On the other hand, the BCF values of Co differed from 0.185 to 0.192 ( $R$. sativus), 0.167 to 0.177 (B. rapa), 0.135 to 0.141 (Z. officinale), 0.104 to 0.109 ( $C$. baccatum), 0.104 to 0.109 (C. frutescens), 0.163 to 0.169 (C. annuum), 0.207 to 0.215 (S. lycopersicum) and 0.274 to 0.283 (C. longa). Higher $\mathrm{BCF}$ values were recorded for $C$. baccatum in canal water irrigation and lower Co values were found in C. longa by sewage water irrigation.

When the $\mathrm{BCF}$ is $\leq 1$, this presents that the plant only absorbs but does not build up heavy metals; when $\mathrm{BCF}>1$, this shows that plant gathers metals in it [31]. BCF values of heavy metals were less than 1 in all vegetables for $\mathrm{Cr}$ and $\mathrm{Co}$, and these results specify that metal bioavailability was low at CWI and SWI sites.

Daily intake of metal and health risk index The DIM values for $\mathrm{Cr}$ and $\mathrm{Co}$ are presented in (Table 3). Among two irrigations, the DIM values for $\mathrm{Cr}$ were 0.0017-0.0023 (R. sativus L.), 0.0006-0.0008 (B. rapa), 0.00140.0018 (Z. officinale), 0.0011-0.0015 (C. baccatum), 0.0008-0.0011 (C. frutescens), 0.0011-0.0014 (C. annuum), 0.0013-0.0016 (S. lycopersicum) and 0.0014-0.0020 ( $C$. longa). In all vegetables, the DIM values for $\mathrm{Cr}$ were higher during sewage water irrigation compared to canal water irrigation. On the other hand, the DIM values for Co were 0.0006-0.0012 ( $R$. sativus), 0.00060.0011 (B. rapa), 0.0004-0.0011 (Z. officinale), 0.0003-0.0007 (C. baccatum), 0.0003-0.0007 (C. frutescens), 0.00050.0011 (C. annuum), 0.0007-0.0013 (S. lycopersicum) and 0.0009-0.0018 (C. longa). In all vegetables, the DIM values for Co were higher in sewage water irrigation compared to canal water irrigation. Daily intake of metal for $\mathrm{Cr}$ and $\mathrm{Co}$ in present findings was found within the similar range given by Ahmad et al. [12].

The results revealed that HRI of $\mathrm{Cr}$ and $\mathrm{Co}$ was less than 1 in each vegetable which was below the permissible limit. To determine the health risk associated with heavy metal contamination of plants grown locally, estimated exposure and risk index were calculated. In all vegetables, the HRI values for $\mathrm{Cr}$ and $\mathrm{Co}$ were higher in sewage water irrigation compared to canal water irrigation 
(Table 3). In the present study, the HRI values of $\mathrm{Cr}$ and $\mathrm{Co}$ fell under the safe limit of HRI and were considered fit for human consumption. The present study results were relatively identical to the observations of Zhuang et al. [32].

\section{Pollution load index}

Values of PLI for Cr and Co of two study sites are given in Table 4. The PLI values of $\mathrm{Cr}$ in soil samples were 0.0140 and 0.0280 for CWI and SWI treatments, respectively. On the other hand, the PLI values of Co for soil samples were 0.1099 and 0.2103 for CWI and SWI treatments, respectively. Contamination level in soil can be explored using PLI. This index provides a simple and comparative means for assessing the quality of different combinations of water irrigation. As described by Tomlinson et al. [33], a value of zero indicates no risk, whereas a value of one and values above one would indicate progressive deterioration of the site irrigated with this water quality.

Table 1. Analysis of variance and mean values of chromium and cobalt $(\mathrm{mg} / \mathrm{kg})$ in soil and vegetables treated with canal and sewage water

\begin{tabular}{|c|c|c|c|c|c|c|}
\hline \multirow{2}{*}{ Soil } & \multicolumn{3}{|c|}{ Chromium } & \multicolumn{3}{c|}{ Cobalt } \\
\cline { 2 - 3 } & \multicolumn{2}{|c|}{ Mean \pm S.E. } & Mean & \multicolumn{2}{c|}{ Mean \pm S.E. } & Mean \\
\cline { 2 - 3 } \cline { 5 - 7 } & CWI & SWuare & CWI & SWI & Square \\
\hline R. sativus & $0.900 \pm 0.198$ & $1.800 \pm 0.063$ & $9.720^{*}$ & $0.575 \pm 0.066$ & $1.100 \pm 0.132$ & $12.600^{* *}$ \\
\hline B. rapa & $0.110 \pm 0.184$ & $0.216 \pm 0.198$ & $7.375^{*}$ & $0.096 \pm 0.031$ & $0.195 \pm 0.060$ & $2.127^{\text {ns }}$ \\
\hline Z. officinale & $0.241 \pm 0.113$ & $0.470 \pm 0.227$ & $42.074^{* *}$ & $0.078 \pm 0.017$ & $0.155 \pm 0.018$ & $15.584^{* *}$ \\
\hline C. baccatum & $0.196 \pm 0.063$ & $0.393 \pm 0.075$ & $2.928^{\text {ns }}$ & $0.060 \pm 0.014$ & $0.120 \pm 0.027$ & $3.840^{\text {ns }}$ \\
\hline C. frutescens & $0.144 \pm 0.126$ & $0.288 \pm 0.126$ & $39.089^{* *}$ & $0.060 \pm 0.005$ & $0.120 \pm 0.011$ & $24.686^{*}$ \\
\hline C. annuum & $0.190 \pm 0.075$ & $0.378 \pm 0.184$ & $16.892^{*}$ & $0.094 \pm 0.013$ & $0.186 \pm 0.025$ & $10.654^{*}$ \\
\hline S. lycopersicum & $0.221 \pm 0.198$ & $0.428 \pm 0.113$ & $17.947^{\text {ns }}$ & $0.119 \pm 0.013$ & $0.236 \pm 0.025$ & $17.191^{*}$ \\
\hline C. longa & $0.250 \pm 0.184$ & $0.525 \pm 0.063$ & $7.118^{*}$ & $0.158 \pm 0.003$ & $0.311 \pm 0.005$ & $639.254^{* * *}$ \\
\hline
\end{tabular}

$*, * *, * * *=$ significant at $0.05,0.01$ and 0.001 levels, $\mathrm{ns}=$ non-significant

Table 2. Bio-concentration factor for vegetable/soil system for chromium and cobalt

\begin{tabular}{|c|c|c|c|c|}
\hline \multirow{2}{*}{ Vegetables } & \multicolumn{2}{|c|}{ Chromium } & \multicolumn{2}{c|}{ Cobalt } \\
\cline { 2 - 5 } & CWI & SWI & CWI & SWI \\
\hline R. sativus & 0.336 & 0.333 & 0.185 & 0.192 \\
\hline B. rapa & 0.122 & 0.120 & 0.167 & 0.177 \\
\hline Z. officinale & 0.268 & 0.261 & 0.135 & 0.141 \\
\hline C. baccatum & 0.218 & 0.218 & 0.104 & 0.109 \\
\hline C. frutescens & 0.160 & 0.160 & 0.104 & 0.109 \\
\hline C. annuum & 0.211 & 0.210 & 0.163 & 0.169 \\
\hline S. lycopersicum & 0.246 & 0.238 & 0.207 & 0.215 \\
\hline C. longa & 0.278 & 0.292 & 0.274 & 0.283 \\
\hline
\end{tabular}


Table 3. Daily intake of metals and health risk index of chromium and cobalt contents via intake of different vegetables from canal and sewage wastewater irrigated sites

\begin{tabular}{|c|c|c|c|c|c|c|c|c|}
\hline \multirow{3}{*}{ Vegetables } & \multicolumn{2}{|c|}{ Chromium } & \multicolumn{2}{|c|}{ Cobalt } & Chro & nium & \multicolumn{2}{|c|}{ Cobalt } \\
\hline & \multicolumn{4}{|c|}{ Daily intake of metal } & \multicolumn{4}{|c|}{ Health risk index } \\
\hline & CWI & SWI & CWI & SWI & CWI & SWI & CWI & SWI \\
\hline R. sativus & 0.0017 & 0.0023 & 0.0011 & 0.0023 & 0.0006 & 0.0012 & 0.0140 & 0.0280 \\
\hline B. rapa & 0.0006 & 0.0008 & 0.0004 & 0.0008 & 0.0006 & 0.0011 & 0.0127 & 0.0258 \\
\hline Z. officinale & 0.0014 & 0.0018 & 0.0009 & 0.0018 & 0.0004 & 0.0009 & 0.0103 & 0.0205 \\
\hline C. baccatum & 0.0011 & 0.0015 & 0.0007 & 0.0015 & 0.0003 & 0.0007 & 0.0079 & 0.0159 \\
\hline C. frutescens & 0.0008 & 0.0011 & 0.0005 & 0.0011 & 0.0003 & 0.0007 & 0.0079 & 0.0159 \\
\hline C. апnиит & 0.0011 & 0.0014 & 0.0007 & 0.0014 & 0.0005 & 0.0011 & 0.0124 & 0.0247 \\
\hline S. lycopersicum & 0.0013 & 0.0016 & 0.0008 & 0.0016 & 0.0007 & 0.0013 & 0.0157 & 0.0313 \\
\hline C. longa & 0.0014 & 0.0020 & 0.0009 & 0.0020 & 0.0009 & 0.0018 & 0.0208 & 0.0412 \\
\hline
\end{tabular}

Table 4. Pollution load index for chromium and cobalt in soil

\begin{tabular}{|c|c|c|c|c|}
\hline \multirow{2}{*}{ Sites } & \multicolumn{2}{|c|}{ Chromium } & \multicolumn{2}{c|}{ Cobalt } \\
\cline { 2 - 5 } & $\begin{array}{c}\text { Reference soil } \\
\text { value }\end{array}$ & PLI & $\begin{array}{c}\text { Reference soil } \\
\text { value }\end{array}$ & PLI \\
\hline CWI & 9.07 & 0.0140 & 9.1 & 0.1099 \\
\hline SWI & 9.07 & 0.0280 & 9.1 & 0.2103 \\
\hline
\end{tabular}

Source $^{\mathrm{a}}=$ Singh et al. [31], Source ${ }^{\mathrm{b}}=$ Dutch standards [34]

\section{Conclusion}

Scarcity of fresh water resources has diverted the attention of famers towards the use of sewage water to get optimum yield of crops. Sewage water contains surplus amount of toxic metals and essential plant nutrients. The results of current work revealed that the levels of $\mathrm{Cr}$ and $\mathrm{Co}$ in all vegetables were within the acceptable limits given by FAO/WHO. The bio-concentration factor and HRI for $\mathrm{Cr}$ and $\mathrm{Co}$ was less than 1 indicating safe consumption of vegetables. Supporting the findings of this study with new data will be useful for the health of the people living in the region.

\section{Authors' contributions}

Conceived and designed the experiments: ZI Khan, I Ugulu, K Ahmad \& IR Noorka, Performed the experiments: A Nisar, $\mathrm{H}$ Bashir, M Munir, F Shaheen, A Ashfaq, R
Abdullah, S Iqbal \& F Batool, Analyzed the data: K Wajid, M Nadeem, TM Qureshi \& IS Malik, Contributed reagents/ materials/ analysis tools: K Nawaz, MJZ Rasheed, A Hussain, H Memona, M Shehzadi \& M Sana, Wrote the paper: N Mehmood, F Arshad, S Akhtar, T Abbas, S Ullah, H Muqadas \& S Siddique.

\section{Acknowledgements}

The Higher Education Commission, Pakistan is acknowledged for providing the financial support through the research project \#20$3546 / \mathrm{NRPU} / \mathrm{R} \& \mathrm{D} / / 14 / 536$ to the 4 th author.

\section{References}

1. Ugulu I (2015). Determination of heavy metal accumulation in plant samples by spectrometric techniques in Turkey. Appl Spectros Rev 50(2): 113-151.

2. Dogan Y, Baslar S \& Ugulu I (2014a). A study on detecting heavy metal 
accumulation through biomonitoring: Content of trace elements in plants at Mount Kazdagi in Turkey. Appl Ecol Environ Res 12(3): 627-636.

3. Chen XW, Wong JTF, Mo WY, Man YB, Ng CWW \& Wong MH (2016). Ecological performance of the restored south east new territories (SENT) landfill in Hong Kong (2000-2012). Land Degrad Develop 27(6): 1664-1676.

4. Khan ZI, Ugulu I, Sahira S, Ahmad K, Ashfaq A, Mehmood N \& Dogan Y (2018a). Determination of toxic metals in fruits of Abelmoschus esculentus grown in contaminated soils with different irrigation sources by spectroscopic method. Int $J$ Environ Res 12:503-511.

5. Singh S \& Kumar M (2006). Heavy metal load of soil, water and vegetables in periurban Delhi. Environ Monitor Assess 120: 71-79.

6. Nadeem M, Qureshi TM, Ugulu I, Riaz MN, An QU, Khan ZI, Ahmad K, Ashfaq A, Bashir H \& Dogan Y (2019). Mineral, vitamin and phenolic contents and sugar profiles of some prominent date palm (Phoenix dactylifera) varieties of Pakistan. Pak J Bot.

7. Jarup L (2003). Hazards of heavy metal contamination. British Medic Bullet 68: 167-182.

8. Unver MC, Ugulu I, Durkan N, Baslar S \& Dogan Y (2015). Heavy metal contents of Malva sylvestris sold as edible greens in the local markets of Izmir. Ekoloji 24(96): 13-25.

9. Dogan Y, Ugulu I \& Baslar S (2010). Turkish red pine as a biomonitor: a comparative study of the accumulation of trace elements in needles and barks. Ekoloji 19(75): 88-96.

10. Ugulu I, Unver MC \& Dogan Y (2016). Determination and comparison of heavy metal accumulation level of Ficus carica bark and leaf samples in Artvin, Turkey. Oxid Commun 39(1): 765-775.

11. Dogan Y, Unver MC, Ugulu I, Calis M \& Durkan N (2014b). Heavy metal accumulation in the bark and leaves of
Juglans regia planted in Artvin City, Turkey. Biotech Biotechnol Equip 28(4): 643-649.

12. Ahmad K, Nawaz K, Khan ZI, et al. (2018). Effect of diverse regimes of irrigation on metals accumulation in wheat crop: An assessment-dire need of the day. Fresen Environ Bullet 27(2): 846-855.

13. Durkan N, Ugulu I, Unver MC, Dogan Y $\&$ Baslar S (2011). Concentrations of trace elements aluminum, boron, cobalt and tin in various wild edible mushroom species from Buyuk Menderes River Basin of Turkey by ICP-OES. Trace Elem Electroly 28(4): 242-248.

14. Khan ZI, Ugulu I, Umar S, Ahmad K, Mehmood N, Ashfaq A, Bashir H \& Sohail M (2018b) Potential toxic metal accumulation in soil, forage and blood plasma of buffaloes sampled from Jhang, Pakistan. Bullet Environ Contam Toxicol 101: 235-242.

15. Chojnacka K, Chojnaiki A, Gorecka H \& Gorecki H (2005). Bioavailability of heavy metals from polluted soils to plants. Sci Total Environ 337: 175-182.

16. Khan ZI, Ugulu I, Ahmad K, Yasmeen S, Noorka IR, Mehmood N \& Sher M (2018c) Assessment of trace metal and metalloid accumulation and human health Risk from vegetables consumption through spinach and coriander specimens irrigated with wastewater. Bull Environ Contam Toxicol.

17. Radwan MA \& Salama AK (2006). Market basket survey for some heavy metals in Egyptian fruits and vegetable. Food Chem Toxicol 44: 1273-1278.

18. Ugulu I, Dogan Y, Baslar S \& Varol O (2012). Biomonitoring of trace element accumulation in plants growing at Murat Mountain. Int J Environ Sci Tech 9: 527534. https://doi.org/10.1007/s13762-0120056-4

19. Sajjad K, Farooq R, Shahbaz S, Khan MA \& Sadique M (2009) Health risk assessment ofheavy metals for population via consumption of vegetables. World Applied Sci J 6: 1602-1606. 
20. Cui YJ, Zhu YG, Zhai RH, Chen DY, Huang YZ, Qui Y \& Liang JZ (2004). Transfer of metals from near a smelter in Nanning, China. Environ Int 30: 785-791.

21. WHO (World Health Organization) (1996). Trace Elements in Human Nutrition and Health. World Health Organization, Geneva.

22. Haiyan W \& Stuanes AO (2003). Heavy metal pollution in air-water-soil-plant system of Zhuzhou City, Hunan Province, China. Water Air Soil Pollut 147(1-4): 79107.

23. Gupta N, Khan DK \& Santra SC (2008). An assessment of heavy metal contamination in vegetables grown in wastewater irrigated areas of Titagarh, West Bengal, India. Bullet Environ Contam Toxicol 80: 115-118.

24. FAO/WHO (2001). Codex Alimentarius Commission. Food additive and contaminants. JointFAO/ WHO Food Standards Programme, ALINORM 01/ 12A, pp 1-289.

25. Chiroma TM, Ebewele RO \& Hymore FK (2014). Comparative assessment of heavy metal levels in soil, vegetables and urban grey wastewater used for irrigation in Yola and Kano. Int Refereed J Eng Sci 3:1-9.

26. Nagajyoti PC Dinakar N Prasad TNVKV Suresh C \& Damodharam T (2008). Heavy metal toxicity: Industrial effluent effect on groundnut (Arachis hypogaea L.) seedlings. J Appl Sci Res 4(1): 110-121.

27. Cao H, Chen J, Zhang J, Zhang H, Qiao L \& Men Y (2010). Heavy metals in rice and garden vegetables and their potential health risks to inhabitants in the vicinity of an industrial zone in Jiangsu, China. $J$ Environ Sci 22(11): 1792-1799.

28. Guerra F, Trevizam AR, Muraoka T, Marcante NC \& Canniatti-Brazaca SG
(2012). Heavy metals in vegetables and potential risk for human health. Scientia Agricola 69(1): 54-60.

29. Anwanghe BA, Agbaji EB, Gimba CE \& Ajibola VO (2013). Seasonal variations in trace metals contents of some vegetables grown on irrigated farmlands along the Bank of River Benue within Makurdi Metropolis. J Natural Sci Resour 3: 74-82.

30. Kalagbor IA, Barisere V, Barivule G, Barile S \& Bassey C (2014). Investigation of thepresence of some heavy metals in four edible vegetables, bitter leaf (Vernonia

amygdalina), scent leaf (Ocimum gratissimum), water leaf (Talinum triangulare) and fluted pumpkin (Telfairia occidentalis) from a cottage farm in Port Harcourt. Research

J Environ Earth Sci 6(1): 18-24.

31. Singh A, Sharma RK, Agrawal M \& Marshall FM (2010). Health risk assessment of heavy metals via dietary intake of food stuffs from the wastewater irrigated site of a dry tropical area of India. Food Chem Toxicol 48(2): 611-619.

32. Zhuang P, McBride MB, Xia H, Li N \& Li $Z$ (2009). Health risk from heavy metals via consumption of food crops in the vicinity of Dabaoshan mine, South China. Sci Total Environ 407(5): 15511561.

33. Tomlinson DL, Wilson JG, Harris CR \& Jeffrey DW (1980). Problems in the assessment of heavy metal levels in estuaries and the formation of a pollution index. Helgolaender Meeresunter 33: 566575.

34. Dutch Standard (2000). Circular on target values and intervention values for soil remediation. 